\title{
Gemistocytic Astrocytoma
}

National Cancer Institute

\section{Source}

National Cancer Institute. Gemistocytic Astrocytoma. NCI Thesaurus. Code C4321.

A rare variant of diffuse astrocytoma. It is characterized by the presence of a conspicuous, though variable, fraction of gemistocytic neoplastic astrocytes.

Gemistocytes are round to oval astrocytes with abundant, glassy, non-fibrillary cytoplasm which appears to displace the dark, angulated nucleus to the periphery of the cell. To make the diagnosis of gemistocytic astrocytoma, gemistocytes should amount to more than approximately $20 \%$ of all tumor cells. (Adapted from WHO) 